\title{
Evaluation of the UK Islamic Banking System, Challenges and Prospects
}

\author{
Shamsalden Aziz Salh \\ Soran University, Faculty of Law, Political Science and Management, Law Department
}

\begin{abstract}
Under the UK financial law, Islamic banks are treated in the same way as conventional banks-there is no special Islamic banking law, nor is there any provision under the current banking law system for Islamic banks. The Financial Services Authority (FSA), the Financial Conduct Authority (FCA) and the Prudential Regulatory Authority (PRA) regulate and supervise all financial institutions, and this includes Islamic banks. However, the only official document to mention Islamic banks is a paper issued by Her Majesty's Treasury, which simply explains Islamic banking rather than setting out any rules or regulations. The UK banking system's policy is to not favoritise any specific type of financial institution; all institutions are treated equally, without giving Islamic banks a special treatment.The UK government has tried to facilitate and assist Islamic banks with developing and conducting their activities effectively. many obstacles that previously faced Islamic banks in the country have either been removed or at least reduced to some extent. These efforts have been made to open the gate for Islamic banks to enter the UK banking market and develop their business there. For example, as described in this paper, some changes have been made concerning tax regulation and legislation to help facilitate Islamic banking transactions. In addition, the Islamic Bank of Britain's definition of 'deposit' has been modified to become more acceptable. Generally speaking, the Islamic banking industry in the UK is managed and organised very well, regardless of there being no special Islamic banking law. However, some issues are still existing and faced by Islamic banks in the UK, such as lack of Islamic banking law, shortage of experts, and lack of transparency. Thus, this paper evaluated and criticised the Islamic banking system of the UK and attempted to find out solutions for all these issues.
\end{abstract}

Keywords: the United Kingdom, Islamic Banks and Challenges

DOI: $10.7176 / \mathrm{PPAR} / 10-8-04$

Publication date:August $31^{\text {st }} 2020$

\section{1- Introduction}

The UK is an important and well-managed country in many ways. Its legal system is based on common law, and its economy is strong due to the strength of its economic system. The financial sector represents a key and welldeveloped part of the country's economy and has a direct and effective impact on the development of the country as a whole. Accordingly, the UK has a well organised financial system, and all financial institutions are treated on the same basis. As a growing part of the financial sector in the country, Islamic finance has a clear role in contributing to the financial industry, and Islamic banking in the UK is becoming a fast-evolving player. The UK government is, therefore, making efforts to provide all facilities necessary for Islamic banks to take their place in the country's financial market.

As mentioned in a document released by Her Majesty's Treasury on the development of Islamic finance in the UK, evidence of this sector's remarkable growth can be seen in the figures for Sharia-compliant assets in the country, which are the highest in Europe. The capital city, London, has an obvious position not only as a leader for international finance but also as a centre for Islamic finance in the West. Here, Islamic banks are regulated alongside other financial institutions in the UK by the Financial Services Authority under the Financial Services and Markets Act 2000. ${ }^{1}$ In addition, the Financial Conduct Authority (FCA) and the Prudential Regulatory Authority (PRA) are two important regulators for financial institutions in the UK, including Islamic banks.

At present, the UK is considered not simply as a financial centre for Islamic banks in the West, but also as a gateway for Islamic banks to other parts of the West, and Europe in particular. Because of this, many rich Middle Eastern investors come to the UK to invest their wealth, yet the country does not have special Islamic banking law. Since conventional banks in the UK conduct their operations in a different way to Islamic banks, this begs the question of how Islamic banks in the UK run their business, and what law governs these banks. In this paper, therefore, the Islamic banking industry in the UK is evaluated under the country's current financial system in an attempt to elucidate how the banks are so well-organised even without a special legal framework for supervision and regulation of this type of banking.

\section{2- The UK Company System}

There are two systems for corporate governance used in the world, namely the one-tier board and the two-tier board.

${ }^{1} \mathrm{H}$ M Treasury "The development of Islamic finance in the UK: the Government's perspective" (2008), 3. 
Some countries choose to follow the one-tier board system while others use the two-tier board system. In some other countries, the law gives the option for a company to have either a one-tier or a two-tier board. ${ }^{2}$

In European countries, corporate governance systems vary as above, with some countries, such as the UK and Spain, following the one-tier board system, others, for example, Germany and the Netherlands, following the two-tier system, and some, namely France and Italy, giving companies the entitlement to choose either one-tier or two-tier board system. As stated above, in the UK the one-tier board system is followed, which comprises both executive and non-executive directors. Executive directors are responsible for running the business, working fulltime and monitoring the performance of the company's activities. In contrast, non-executive directors have a dual function of developing strategy and monitoring the execution of the business. ${ }^{3}$

In the UK, the role of the non-executive directors is very important in the company. They scrutinize the performance of the management in meeting agreed goals and objectives, and monitor the reporting of company performance. They represent the shareholders' interests, and as such, they supervise and oversee the management of the company as performed by the executive directors. Non-executive directors also have the power to appoint or remove executive directors where necessary. ${ }^{4}$

According to the UK Combined Code of Corporate Governance, a company's board is responsible for leading the company within a legal framework of prudential measures for controlling the company, and for minimising and managing risk. It is also a responsibility of the board to set the company's strategic goal. The main function of the board is therefore to run and manage the company's business. The board must monitor the company's operations and ensure that all the necessary tools and human resources are in place to enable the company to meet its objectives. ${ }^{5}$

The board should include a balance of executive and non-executive directors; in particular independent nonexecutive directors to ensure no individual or small group of individuals can control the decisions of the board or exploit their power to make an individual decision. Each board member, executive or non-executive, has its clear role and responsibility remit, according to the UK Combined Code of Corporate Governance. There is no unlimited power of decision given to any one individual. In many ways, the directors are acting as a legal agent for the company; they conduct business and perform legal actions. ${ }^{6}$

Directors are thus considered as trustees of the company - in the eyes of the law, they are trustees as far as the assets that they deal with legal transactions in which they involve the company that they run are considered.

\section{3- Compatibility of the Islamic Banking System with the One-tier Board System}

The UK applies a one-tier board system for corporate governance of companies under the UK Companies Act 2006. In relation to the legal aspect, however, the Companies Act 2006 is very flexible concerning the structural issues of companies. As a result, even though UK companies follow a one-tier board system, the Companies Act 2006 does not explicitly require a single board. The only condition that the Companies Act makes regarding the structure is the requirement of a minimum number of directors of a company. ${ }^{7}$

In the case of Islamic banks, there is the Sharia Supervisory Board, which is responsible for ensuring that all products and transactions are compatible with Sharia law. This board does not contradict UK law since although the structure of Islamic banks is a two-tier board, this is not considered a problem under UK banking or company law. The UK's practice of having a one-tier board, and especially non-executive directors, is deemed similar to the Islamic banking Sharia Supervisory Board. Both the Sharia Supervisory Board and the non-executive board have the same function, which is to supervise the company's management and operations. Another similarity is that both of them, in an indirect way, is contributing to the bank's management, since the Sharia Supervisory Board has the power to terminate any transaction that is not compatible with Sharia law, thus having an input in the management of the company. ${ }^{8}$

\section{4- Islamic Banking System in the UK}

The UK capital, London, plays an important role in developing the country's financial sector. Around 310,000 employees are working in the financial services sector in London, and the capital comes only after New York as the second city in the world in terms of its vital position concerning the finance industry. Internationally, more than 20 percent of all international bank lending and more than 30 percent of all foreign exchange transactions take place through the offices of banks operating in London. In Europe, London has a high status and is considered

\footnotetext{
${ }^{2}$ R Bohinc 'One or Two-tier Corporate Governance Systems in Some EU And Non EU Countries' 2011, 8:1, Megatrend Review, 57.

${ }^{3}$ B Marina 'Two-Tier Boards for the Governance of Banks' (June 4, 2009). EFMA Annual Conference, 1.

${ }^{4} \mathrm{R}$ Bohinc 'One or Two-tier Corporate Governance Systems in Some EU And Non EU Countries' 2011, 8:1, Megatrend Review, 62.

${ }^{5}$ Ibid 61 .

${ }^{6}$ Ibid 62

${ }^{7}$ Aldohni, Islamic banking challenges modern Corporate Governance: The Dilemma of the Sharia Supervisory Board, Company Lawyer, 2008, 22,4

${ }^{8}$ Ibid 6.
} 
as a centre for the European financial market. ${ }^{1}$

In order to understand Islamic banking law, it is necessary to first know the exact sources of Islamic financial law. The first source of Islamic financial law is the Quran, which is the holy book for Muslims, followed by the Sunnah of the Prophet Muhammad ((peace be upon him), which contains the sayings and deeds of the Prophet. The third source of Islamic financial law comes from the opinions of experts in the field of Islamic law, who have their own idea about certain issues but whose proposals should not conflict with the two main sources of Islam. ${ }^{2}$

In the UK, special Islamic banking law does not exist for the regulation and supervision of Islamic banks; but the government facilitates ways for Islamic banks to conduct their activities. As mentioned in the HM Treasury document, the UK government, through Her Majesty's Treasury, is working to regulate Islamic finance in the country. That was the reason for Her Majesty's Treasury publishing a document to evaluate and assist Islamic finance in the UK. There were two main aims implicit in this document. The first was to support the country's financial sector by making the country a gateway for international Islamic finance, and the second was to make sure that everyone in the country has the right to access competitively-priced financial products, regardless of their religion or faith. ${ }^{3}$ In this way, Her Majesty's Treasury and Her Majesty's Revenue and Customs have supported the development of Islamic finance in the country. The most important practical action they took was the change of tax legislation to reduce the heavy load on the Islamic banking industry.

The UK government treats both conventional and Islamic banks equally, so both types of banks should be taxed. The UK government is trying to eliminate tax obstacles that have hitherto hampered the development of Islamic banking operations. Despite this assistance, however, the government does not give Islamic banks special treatment over other forms of finance ${ }^{4}$

\section{5- Regulation and Supervision of Islamic Finance in the UK}

In the UK, the FSA - has a clear vision that all financial firms should be treated equally. There is no discrimination; according to the FSA's regulations, all financial institutions are subject to the same rules and regulations, regardless of their country of origin or their faith and religion. ${ }^{5}$ Islamic banks thus automatically find themselves under the FSA umbrella, without the need to be given any special position or place. This equality makes the FSA a unique and vital regulator in the UK under the Financial Services and Market Act 2000.

Furthermore, in the UK the Financial Conduct Authority (FCA) and the Prudential Regulatory Authority (PRA) together regulate and supervise Islamic financial institutions. ${ }^{6}$ The FCA regulates and oversights Islamic finance in the UK. Thus, all Islamic banks in the UK are required to be authorised and licensed by the FCA. On the other hand, The PRA holds responsibility for the prudential regulation of banks, building societies, credit unions, insurers and major investment firms; including Islamic banks in the UK. In fact, The FCA and the PRA deal with Islamic banks on the same bases as conventional banks. In addition, Islamic banks in the UK are considered to be 'financial institutions' for the purposes of the Financial Services and Markets Act 2000. Islamic banks are subject to sanctions and penalties in the same way as conventional banks. ${ }^{7}$

\section{6- The Islamic Bank of Britain as the First Wholly Islamic Bank}

The Islamic Bank of Britain was given a license in 2004, making it the first fully Islamic bank in the UK to be authorized under the FSA regulations, a process that took about 18 to 24 months. The biggest problem that faced the bank was the definition of the term 'deposit'. The definition of deposit as understood in the UK is "a sum of money paid on terms under which it will be repaid either on-demand or in circumstances agreed by parties." According to this definition, the depositors are assured of full repayment, even in the case of the bank's insolvency. ${ }^{8}$

For Islamic banks, the situation is different, because, in Islamic banking contracts, a system of profit and loss sharing is followed, meaning that the profit and risk are shared between the bank and the depositor, based on their agreement. Therefore, the customer should bear in mind that the deposit is not guaranteed, and so Sharia law regulators ask clients to accept the risk of loss of their original capital. Such loss- or risk-sharing with customers is not acceptable under the definition of a deposit in the UK. As a result, this has previously been a major issue between the FSA and the Islamic Bank of Britain. However, the bank found an interim solution for this issue by

\footnotetext{
${ }^{1}$ A Aldohni 'the Emergence of Islamic banking in the UK: A comparative Study with Muslim Countries' (2008), 22, Arab law Quarterly, 190. ${ }^{2}$ S M Nizami 'Islamic Finance: The United Kingdom's Drive to Become The Global Islamic Finance Hub and The United States' Irrational Indifference to Islamic Finance'(2011), 34:1, Suffolk Transnational Law Review, 221-222.

${ }^{3} \mathrm{H}$ M Treasury "The development of Islamic finance in the UK: the Government's perspective” (2008), 13.

${ }^{4}$ Ibid 15.

${ }^{5}$ M Ainley, A Mashayekhi, R Hicks, A Rahman and A Ravalia 'Islamic Finance in the UK: Regulation and Challenges' Financial services Authority (2007), 11

${ }^{6}$ Kathryn O'Sullivan, Minority Religions under Irish Law: Islam in National and International Context ( Leiden : Brill, Boston 2019 ) 164.

${ }^{7}$ The Islamic Finance and Markets Review, John Dewar and Munib Hussain, October 2019, https://thelawreviews.co.uk/edition/the-islamicfinance-and-markets-review-edition-4/1209545/united-kingdom, accessed 12 July 2020.

${ }^{8}$ Ibid
} 
stating that, legally, its depositors are entitled to full repayment of their deposit, a promise which was acceptable under the FSA's requirements. Customers also have the right to turn down deposit protection after the event on religious grounds and may choose instead to be repaid under the Sharia-compliant risk-sharing system and lossbearing formula, in line with their religious beliefs. ${ }^{1}$

Another point of interest here is the role of the Sharia supervisory board. The Islamic Bank of Britain has had to explain the role and responsibility of the Sharia Board to the FSA. The exact role of a board is solely an advisory one, and it should not interfere in managing the day-to-day banking decisions and management. This is one of the FSA's key requirements. ${ }^{2}$ It seems that the flexibility of the FSA about types of company boards has paved the way for Islamic banking to become established in the UK.

\section{7- Challenges Face Islamic Banking in the UK}

The financial sector like other sectors has faced some difficulties and challenges, some of them are called internal challenges while some others are called external challenges. Islamic banks as a part of the financial sector are not out of having some challenges and issues. There are some general challenges which are faced by both conventional and Islamic banks while some challenges are faced by one of them. Islamic banks in the world have some difficulties including the UK's' Islamic banks. At the same time maybe, some challenges can be found only in the UK or in some non-Muslim countries in the west. Below are some challenges which are faced by the UK's' Islamic banks:

\section{7-1- Absence of Special Islamic Banking Law}

For Islamic banking to have strong regulation and supervision there must be a specific Islamic banking law or general banking law with some provisions for Islamic banks. The law should explain and verify the nature and definition of Islamic banks and determine the relationship between the central bank and those banks and also their relation with other conventional banks. The legal framework must include provisions that specified conditions for licensing Islamic banks and clarify the permissible forms of finance. Besides, laws should state clearly which higher authority has the power and authority to supervise, view, and evaluate Islamic banks. ${ }^{3}$

Looking at the Islamic banking legal framework in the UK under the shadow of the above explanation, it can be noted that Islamic banks in the UK to some extended suffer from lacking Islamic banking Act.

Even though the Islamic banking sector in the UK has a special position and it is continually developing, at the same time the absence of special Act for this type of bank is an issue. ${ }^{4}$ The UK financial system treats Islamic banks as same as conventional banks with presenting of some facilities to support them and make them have an important role in the UK financial sector. But lacking the specific law can be a challenge for Islamic banking in the UK, in other words, if there is a special law for Islamic banks it will be easier for them to conduct their activities and regulate their operations in a better way. Therefore, the lack of such kind of law can be considered as a challenge for Islamic banks in the UK. Hence, enacting a special Islamic banking Act or adding some provisions for regulating Islamic banks under the current banking law system will be a good solution for the absence of Islamic banking law in the UK.

\section{7-2- Lack of Higher Authority for Evaluating the Sharia Supervisory Boards' Decisions}

As aforementioned, the Sharia Supervisory Board could find its place in the UK company law. In other words, the board proved to be not problematic regarding the structure of company law in the UK. Sharia Supervisory Board can be considered as non-executive directors under a one-tier board system in the UK.

The important point here that should be mentioned is which body will evaluate and investigate the Sharia Supervisory Board's decisions. As in the case of non-executive directors, the Companies Act 2000 does not differentiate between the executive and non-executive directors which uses the term "Director" without any specification. Consequently, both executive and non-executive directors are subject to the same rule, and both of them are evaluated and supervised by the same body which oversees the performance of companies' directors. ${ }^{5}$

In contrast, the Sharia Supervisory Board is not subject to any of these bodies and it is not supervised by any higher authority. It works and decisions cannot be reviewed and assessed by any authority inside or outside the institution. For example, if decisions of two different Islamic banks are different on the same product, then who has the final word, as in Malaysia the Sharia Advisory Council (SAC) has this role. ${ }^{6}$ As a result, the Sharia Supervisory Board is considered as an out of the control or out of the supervision of any higher authority. It is said

\footnotetext{
${ }^{1}$ Ibid

${ }^{2}$ Ibid 12.

${ }^{3}$ L Frrico and M Farhbaksh "Islamic Banking: Issues in Prudential Regulations and Supervision”, Review of Islamic Economics, $2001,10,19$.

${ }^{4}$ M Iqbal, A Ahamad and T Khan "Challenges facing islamic Banking”, Islamic Development Banks, 1998, occasional paper No. 1. 36.

${ }^{5}$ Aldohni, Islamic banking challenges modern Corporate Governance: The Dilemma of the Sharia Supervisory Board, Company Lawyer, 2008, 22,6 .

${ }^{6}$ Ahmad Ibrahim ‘Legal Framework of Islamic Banking’ (1997), IKIM Law Journal, 1:1, 1.
} 
that the board is a real threat to the objectives of modern corporate governance. ${ }^{1}$

The main purpose of the Sharia Supervisory Board is to ensure that all products and transactions of the Islamic bank are compliant with the Sharia law. ${ }^{2}$ Therefore, the board has the power to terminate or correct transactions that they see are not compliant with the Sharia law. As a result, the decision of the board affects the interest of a wide range of parties such as investors and shareholders. Besides, the board's decision affects the bank's interest. This is an expected situation that is because there is not a higher authority for viewing and evaluating the decision of the board, it may lead to loss of confidence by the banks' clients. As a result, some of the depositors withdraw their savings. In this case, the shareholders will face a danger of loss. In this context, corporate governance aims to protect the shareholders, investors, and investment account holders. ${ }^{3}$

However, every Islamic bank has its own Sharia supervisory board, and each of them may have a different view on the same product. The different decisions for the same products sometimes lead to loss of customer's confidence in Islamic banks. Contradicting of each other's decision of the Sharia supervisory board impact the Islamic banking market, which may be depositors withdraw their money from the bank due to lack of confidence in Islamic banks. All these occurrences happened because lack of higher authority to view and evaluate Sharia supervisory board. ${ }^{4}$ It is crucial for Islamic banks to have a higher authority for evaluating and supervising the Sharia Supervisory board's decisions as the non-executive directors are subject to a higher body, and to assure depositors that all decisions made are Sharia law compliant. Another solution is to set up a central Sharia Supervisory Board that supervises all Islamic banks in the country, and this board has been giving power by the FSA.

\section{7-3- Regulation Challenge}

As it was mentioned earlier, the definition of the deposit in the UK is 'a sum of money paid on terms under which it will be repaid either on-demand or in circumstances agreed by parties. The regulators do not give license to any bank unless they assure the customers' full deposit repayment. The capital and the deposit should be guarantee and the client is entitled to demand their money at any time or according to the agreement between the bank and the customer. In the case of Islamic banks, the deposit is not guaranteed because Islamic banking contracts depend on the profit and loss sharing which both banks and clients share in the risk. ${ }^{5}$ Therefore it is one of the biggest challenges that faced Islamic banks in the UK because the FSA does not issue a license to financial institutions that cannot guarantee the customer's deposit. Therefore, there should be some changes in the regulation of Islamic banks in the UK that gives Islamic banks special treatment.

\section{7-4- Shortage of Experts}

The shortage of experts in Islamic banks is considered as a challenge for Islamic banks in the UK. The reason behind the shortage of experts is because Islamic banks are new arrival compare with the conventional one. There are few experts for running Islamic banks, and most of the employees that work in Islamic banking institutions have come with a conventional background. Besides, there are only a few trained employees and managers, some of them have little or no specific training in Islamic banking operations. At present, Islamic banks need experts and managers who understand both Islamic and conventional banking systems ${ }^{6}$. Islamic banks need a sufficient number of experts from scholars, managers, and employees for supporting such kind of development. The shortage of experts is a general issue and it is an issue for all Islamic banks in the world including the UK. Thus, opining training courses and providing sufficient funds for developing human capital for Islamic banks in the UK is necessary.

\section{7-5- Lack of Transparency}

Lack of transparency of Islamic banks in general and in the UK in particular impacts negatively on Islamic banking development. The UK is a home for approximately two million Muslims. ${ }^{7}$ As a result, this should be good support for Islamic banks in this country. The dream for Islamic banks did not come true because Muslim community and clients in the UK do not deal with Islamic banks as it is expected, that is because they think that this type of banks are risky or some of them did not understand about Islamic banking operations, In another word, lack of

\footnotetext{
${ }^{1}$ Aldohni, Islamic banking challenges modern Corporate Governance: The Dilemma of the Sharia Supervisory Board, Company Lawyer, 2008, 22,6

${ }^{2}$ S N Garas and C Pierce 'Shari'a Supervision of Islamic Financial Institutions' (2010), Journal of Financial Regulation and Compliance, 2.

${ }^{3}$ Aldohni, Islamic banking challenges modern Corporate Governance: The Dilemma of the Sharia Supervisory Board, Company Lawyer, 2008, 22,7

${ }^{4}$ Aldohni, Islamic banking challenges modern Corporate Governance: The Dilemma of the Sharia Supervisory Board, Company Lawyer, 2008, 22,7

${ }^{5}$ Y Karbhari, K Naser and Z Sahhin "Problems and Challenges facing the Islamic Banking System in the West: The Case of the UK", Thunderbird International Business Review, 2004, 46:5, 524.

${ }^{6}$ M Iqbal and P Molyneux (2005), Thirty years of islamic Banking: History, Performance and prospects, Palgrave Macmillan, NY, Ed, p 121.

${ }^{7}$ H A Dar and J R Presley "Islamic Finance: A Western Perspective”, International Journal of Islamic Financial Services, 1:1.
} 
transparency is a challenge for Islamic banks. ${ }^{1}$ Islamic banks must clarify the transactions and contracts that they follow. A brief explanation of all activates of the institution is necessary for their customers' confidence. Every financial institution has its annual report to state and mentions what the institution did during this year and disclose all transactions and numbers. This report is not for the customers; there should be some information for the Islamic banks' clients and depositors to know the operations and banking activities to ensure that all transactions they followed are compliant with the Sharia law. Therefore, transparency should be a high priority for Islamic banks to attract more customers and return their confidence.

\section{8- Conclusion}

It is noted that Islamic banking in the UK has reached a developed stage comparing to other European and western countries. In the UK financial law, Islamic banks are treated as same as conventional banks. There is not special Islamic banking law and also there is not any provision under the current banking law system for Islamic banks. It can be said that the UK Islamic banking system is different from other countries' Islamic banking system. As mentioned earlier, FSA, FCA, and PRA regulate and supervise Islamic financial institutions as same as conventional banks.

Besides, Islamic banking has a sizeable role to play in developing the financial sector in the UK. Although specific Islamic banking law does not exist in the UK, and no provision under current banking law can be found, Islamic banks nevertheless appear to be operating efficiently and smoothly. The only document that gives some detail on the Islamic banking sector in the UK is a paper drawn up by Her Majesty's Treasury, which represents the government's perspective on Islamic banks. Due to the flexibility of the Financial Services Authority, Islamic banks have so far been able to overcome all obstacles faced. The one-tier board system and the definition of deposit may not be compatible with the Islamic banking system, but the flexibility of the FSA on these matters has assisted Islamic banks in breaking the ice in the UK market.

In the UK Islamic banks are treated as conventional banks and supervised by the same rules. The Islamic Bank of Britain is the first completely Islamic bank in the UK which got it is license under the FSA authorisation in 2004. Islamic banks in the UK have faced some challenges and difficulties, these challenges are not issued only in the UK but also are considered as a problem in other countries for Islamic banks. Lacking a special law for Islamic banks is the main challenge as maybe some times become a hamper for getting a license for a new applicant as it was noted in the case of Islamic bank of Britain which took 18 to 24 months until got its license. Some other issues such as shortage of experts, regulation challenge, lack of higher authority for evaluating the Sharia Supervisory Boards' decisions, and lack of transparency. In general, despite all difficulties and challenges, Islamic banks in the UK are achieved to a high level.

\section{References}

- A Aldohni 'the Emergence of Islamic banking in the UK: A comparative Study with Muslim Countries' (2008), 22, Arab law Quarterly, 190.

- $\quad$ Ahmad Ibrahim 'Legal Framework of Islamic Banking’ (1997), IKIM Law Journal, 1:1, 1.

- $\quad$ Aldohni, Islamic banking challenges modern Corporate Governance: The Dilemma of the Sharia Supervisory Board, Company Lawyer, 2008, 22, 4

- Marina 'Two-Tier Boards for the Governance of Banks' (June 4, 2009). EFMA Annual Conference, 1.

- H A Dar and J R Presley "Islamic Finance: A Western Perspective", International Journal of Islamic Financial Services, 1:1.

- H M Treasury "The development of Islamic finance in the UK: the Government's perspective” (2008), 3.

- Kathryn O'Sullivan, Minority Religions under Irish Law: Islam in National and International Context ( Leiden : Brill, Boston 2019) 164.

- $\quad$ L Frrico and M Farhbaksh "Islamic Banking: Issues in Prudential Regulations and Supervision”, Review of Islamic Economics, 2001, 10, 19.

- $\quad$ M Ainley, A Mashayekhi, R Hicks, A Rahman and A Ravalia 'Islamic Finance in the UK: Regulation and Challenges' Financial services Authority (2007), 11

- M Iqbal and P Molyneux (2005), Thirty years of Islamic Banking: History, Performance and prospects, Palgrave Macmillan, NY, Ed , p 121.

- $\quad$ M Iqbal, A Ahamad and T Khan "Challenges facing islamic Banking”, Islamic Development Banks, 1998, occasional paper No. 1. 36 .

- $\quad$ R Bohinc 'One or Two-tier Corporate Governance Systems in Some EU And Non-EU Countries' 2011, 8:1, Megatrend Review, 57.

- $\quad$ S M Nizami 'Islamic Finance: The United Kingdom's Drive to Become The Global Islamic Finance Hub and

\footnotetext{
${ }^{1} \mathrm{Y}$ Karbhari, K Naser and Z Sahhin "Problems and Challenges facing the Islamic Banking System in the West: The Case of the UK", Thunderbird International Business Review, 2004, 46:5, 524.
} 
The United States' Irrational Indifference to Islamic Finance'(2011), 34:1, Suffolk Transnational Law Review, 221-222.

- $\quad$ S N Garas and C Pierce 'Shari'a Supervision of Islamic Financial Institutions' (2010), Journal of Financial Regulation and Compliance, 2.

- $\quad$ Y Karbhari, K Naser and Z Sahhin "Problems and Challenges facing the Islamic Banking System in the West: The Case of the UK", Thunderbird International Business Review, 2004, 46:5, 524.

- The Islamic Finance and Markets Review, John Dewar and Munib Hussain, October 2019, https://thelawreviews.co.uk/edition/the-islamic-finance-and-markets-review-edition-4/1209545/unitedkingdom, accessed 12 July 2020. 